\title{
Suitable Glazing Selection for Glass-Curtain Walls in Tropical Climates of India
}

\author{
M. C. Singh and S. N. Garg \\ Centre for Energy Studies, Indian Institute of Technology (Hauz Khas), \\ New Delhi 110016, India \\ Correspondence should be addressed to M. C. Singh, mahbsr@yahoo.co.in
}

Received 24 June 2011; Accepted 21 July 2011

Academic Editors: H. Boyer and G. Li

Copyright ( 92011 M. C. Singh and S. N. Garg. This is an open access article distributed under the Creative Commons Attribution License, which permits unrestricted use, distribution, and reproduction in any medium, provided the original work is properly cited.

How a glass-curtain wall affects the heating and cooling load of a building is analysed. The study includes five types of glazings, which include double-glazed clear glass, double-glazed low-e, and double-glazed solar control. The analysis is for three climates: composite (New Delhi), hot and dry (Jodhpur), and warm and humid (Chennai). An office building is chosen for analysis. The study includes effect of glazed area, orientation, and that of climates, on annual energy consumption. It was found that energy consumption increases linearly with the glazed area and minimum energy consumption is for north orientation. For types of climates considered in this study, a glass-curtain wall, made of solar control glazing (reflective), consumes 6-8\% less energy than the standard window.

\section{Introduction}

In Indian metropolitan cities, a new trend in building construction is coming up: having front façade completely glazed. Mainly, it is from aesthetic point of view, although large glazed area provides more natural light and thereby reduces artificial light requirement. A façade, having 90\% of glazed area and $10 \%$ of frame area, is usually called a glass-curtain wall. Bouden [1] has analysed impact of glasscurtain walls on energy consumption for an office building in Tunisian climate. Seven different glass curtain walls, in four different orientations, with five different percentages of glazed areas ranging from $20 \%$ to $90 \%$, have been analysed. He has found that a glass-curtain wall made of one clear glass and other reflecting glass shows lower energy consumption as compared to a standard size window ( $20 \%$ of area, single glazed clear glass). Bansal et al. [2] have determined glazed area, enough to keep a building thermally comfortable for 3 winter climates of India. They have assumed direct gain through the glazed area absorbed by the building parts as follows: $60 \%$ of the radiation by the floor and $8 \%$ by the ceiling and each of the four walls. It has been found that for an uninsulated building (no insulation in walls/roof),
$30 \%$ glazed area of south wall is sufficient for Delhi's composite climate. For insulated buildings, optimum glazed areas are: 10\%, 20\%, and 30\% for New Delhi, Srinagar, and Leh, respectively. Hamdani and Ahmad [3] have analysed the effect of window parameters on inside temperature of the building for climate of Baghdad in Iraq. Saridar and Elkadi [4] have analysed the effect of different window configurations on daylighting energy consumption in an office building at Beirut. A school building has been analysed in terms of energy consumption in Israel by [5], and it was found that the energy consumption can be reduced up to $50 \%$ for high-performance school building. Johnson et al. $[6,7]$ have studied the annual energy consumption in an office building by using the different types of windows for different climates of USA. Energy performance of a building is influenced by the window size and its orientation $[8,9]$. Energy efficient glazings reduce the heating and cooling load of the buildings, allow natural daylight $[10,11]$, and provide human thermal comfort [12]. The heating demands of the buildings can be reduced by using the low-e windows and insulation on walls and roof. Those buildings which have high internal gains and relatively large-glazed façade in south show the lower demands of heating. Similarly, the cooling 


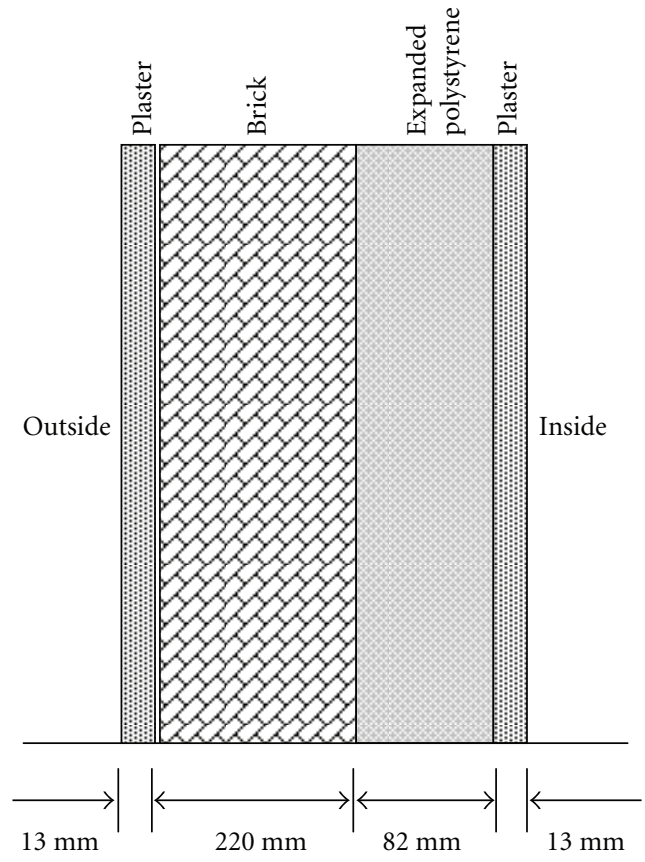

(a)

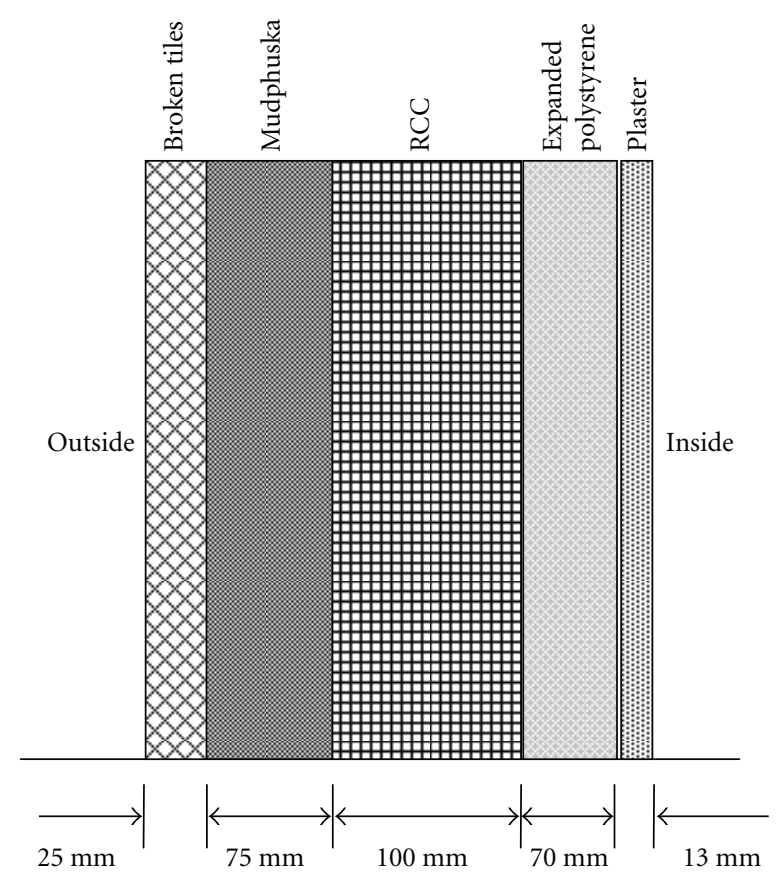

(b)

FIGURE 1: Construction details of (a) walls and (b) roof.

load of the buildings can be reduced by using the solar control windows, and the requisite orientation in which it is minimum can be found $[13,14]$.

In India, large numbers of office buildings are constructed with front façade completely glazed. How glasscurtain wall affects heating/cooling load of a building is not known. In this work, the analysis has been carried out for a well-insulated office building. Effect of climatic conditions, glazings types, glazed areas, and orientations on annual energy consumption has been analysed.

\section{Input Data}

Ten-year weather data (1991-2000) which include monthly mean hourly values of global solar radiation, diffuse solar radiation, relative humidity, and ambient temperature has been procured from India Meteorological Department (IMD), Pune, and this measured data conforms to international standards. IMD Pune acts as the regional radiation center for Asia and maintains the international standards for measurement of surface climate data.

A well-insulated office building with dimensions of $12 \mathrm{~m} \times 8 \mathrm{~m} \times 3 \mathrm{~m}$ has been investigated. The insulation specifications are taken as per Energy Conservation Building Code of India (ECBC-2006) [15]: U-values of its walls and roof are $0.352 \mathrm{~W} / \mathrm{m}^{2} \mathrm{~K}$ and $0.409 \mathrm{~W} / \mathrm{m}^{2} \mathrm{~K}$, respectively. Walls have been constructed with $220 \mathrm{~mm}$ of brick with $13 \mathrm{~mm}$ of cement plaster on both sides. Roof has $13 \mathrm{~mm}$ of cement plaster as innermost surface, $100 \mathrm{~mm}$ of RCC (Reinforced Cement Concrete), $75 \mathrm{~mm}$ of mudphuska (a mixture of soil and rice husk), and $25 \mathrm{~mm}$ of broken tiles as the outermost surface. Insulation layer of expended polystyrene has been provided on both walls as well as roof, immediately after the innermost layer of plaster $(82 \mathrm{~mm}$ for walls and $70 \mathrm{~mm}$ for roof). Details of walls and roof construction are shown in Figure 1. Thermal properties of building materials have been taken as per Bureau of Indian standards (BIS) [16]. Working schedule has been assumed from 8 am to $6 \mathrm{pm}$, with Sunday as holiday. Internal gains from occupants, lighting, and appliances during working hours taken are: person $65 \mathrm{~W}$; computer with monitor $140 \mathrm{~W}$; lighting density $10.8 \mathrm{~W} / \mathrm{m}^{2}$ [15]. The temperature has been controlled at $20^{\circ} \mathrm{C}$ in winter and $25^{\circ} \mathrm{C}$ in summer during working periods and at $18^{\circ} \mathrm{C}$ and $30^{\circ} \mathrm{C}$, respectively, at other times. The ventilation rate considered is $1 \mathrm{ACH}$ (air changes per hour) during the working hours and $0.5 \mathrm{ACH}$ at other times. This study includes three climatic conditions of India: composite (New Delhi, $28^{\circ} 35^{\prime} \mathrm{N}, 77^{\circ} 12^{\prime} \mathrm{E}$ ), hot and dry (Jodhpur, $26^{\circ} 18^{\prime} \mathrm{N}, 73^{\circ} 01^{\prime} \mathrm{E}$ ), and warm and humid (Chennai, $13^{\circ} 00^{\prime} \mathrm{N}, 80^{\circ} 11^{\prime} \mathrm{E}$ ). The climatic data of these locations is shown in Figure 2. It includes monthly mean values of global radiation on horizontal surface, ambient air temperature, relative humidity, and wind speed. In most part of India (except few places at high altitudes), winter is mild and exists for two months only (December and January) and mild heating is required. For air-conditioned buildings, cooling is required for about 8 months, March to October. So this study is mainly from cooling point of view. The emphasis is on the selection of glazing types and their optimum orientation, from cooling point of view. New types of glass and coating are coming up in the market. With the increasing glazed area, the cooling load, in summer, always increases. In winter, it may lead to overheating which necessitates cooling. 


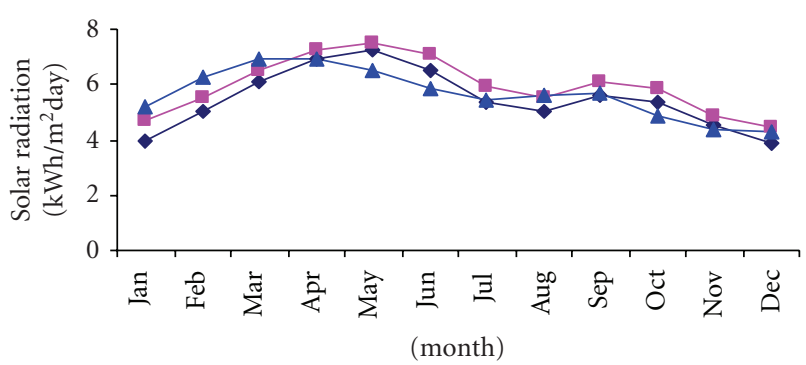

(a)

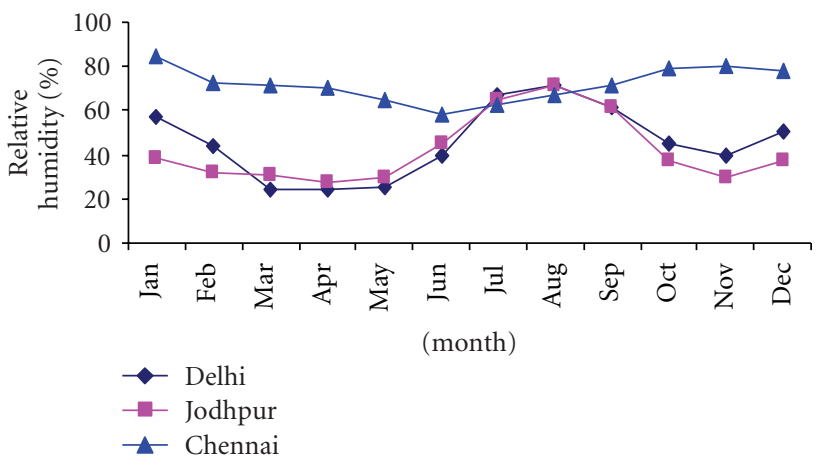

(c)

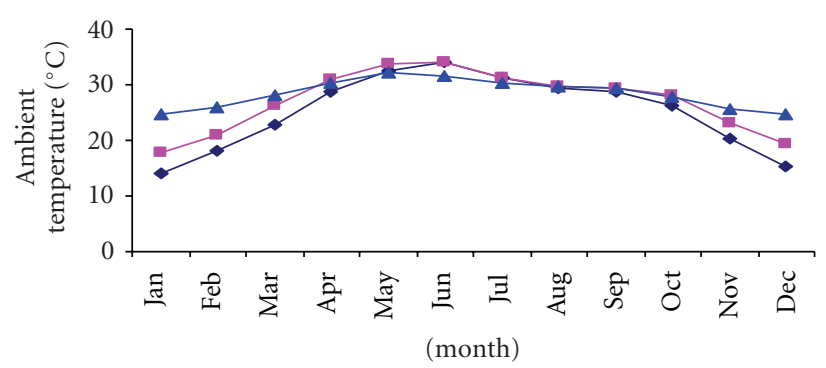

(b)

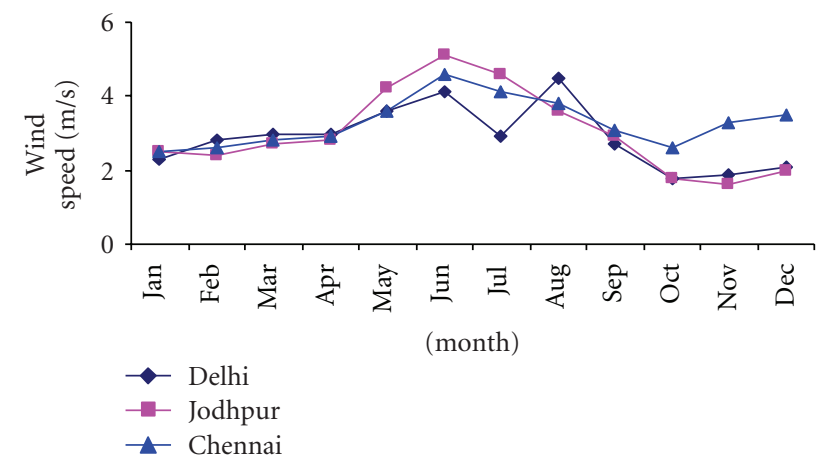

(d)

Figure 2: Climatic data (monthly mean values) for three stations, (a) solar radiation, (b) ambient temperature, (c) relative humidity, and (d) wind speed.

TABLE 1: Different kinds of glass-curtain walls used in this study. The values of both $U$ and $g$ have been computed by WINDOW 5.0.

\begin{tabular}{|c|c|c|c|c|c|}
\hline S. no. & Glazing type & Description & Identity & $U\left(\mathrm{~W} / \mathrm{m}^{2} \mathrm{~K}\right)$ & SHGC* $(g$-value $)$ \\
\hline 1 & $\begin{array}{c}\text { Double glazed, clear glass } \\
\text { window }\end{array}$ & $\begin{array}{l}6 \mathrm{~mm} \text { clear glass }+12 \mathrm{~mm} \\
\text { air space }+6 \mathrm{~mm} \text { clear glass }\end{array}$ & Clear-clear & 2.95 & 0.73 \\
\hline 2 & $\begin{array}{l}\text { Double glazed, low-e } \\
\text { window }\end{array}$ & $\begin{array}{l}6 \mathrm{~mm} \text { low-e glass }+12 \mathrm{~mm} \\
\text { air space }+6 \mathrm{~mm} \text { clear glass }\end{array}$ & Low-e1-clear & 1.80 & 0.68 \\
\hline 3 & $\begin{array}{l}\text { Double glazed, low-e } \\
\text { window }\end{array}$ & $\begin{array}{l}6 \mathrm{~mm} \text { low-e glass }+12 \mathrm{~mm} \\
\text { air space }+6 \mathrm{~mm} \text { clear glass }\end{array}$ & Low-e2-clear & 1.74 & 0.54 \\
\hline 4 & $\begin{array}{l}\text { Double glazed, solar } \\
\text { control (absorptive) } \\
\text { window }\end{array}$ & $\begin{array}{l}6 \mathrm{~mm} \text { solar control } \\
\text { (absorptive) glass }+12 \mathrm{~mm} \\
\text { air space }+6 \mathrm{~mm} \text { clear glass }\end{array}$ & Solar control-abs & 2.80 & 0.24 \\
\hline 5 & $\begin{array}{l}\text { Double glazed, solar } \\
\text { control (reflective) window }\end{array}$ & $\begin{array}{c}6 \mathrm{~mm} \text { solar control } \\
\text { (reflective) glass }+12 \mathrm{~mm} \\
\text { air space }+6 \mathrm{~mm} \text { clear glass }\end{array}$ & Solar control-ref & 1.95 & 0.10 \\
\hline
\end{tabular}

* Solar heat gain coefficient.

\section{Methodology}

Energy performance of the building has been investigated by using TRNSYS 16 [17]. TRNSYS Type 56 is a transient simulation module used for thermal analysis of buildings. The TRNSYS project model has three main features: weather data reader, solar radiation processor, and TRNBuild. Weather data reader reads the data from standard file format such as TMY2 (Typical Meteorological Year version-2) and then links it with the radiation processor. The solar radiation processor calculates the radiation on inclined surfaces. In
TRNBuild, user can create input data for buildings. This data includes building envelope details such as walls, roof, floor, window, and operational behavior of the building such as heating and cooling schedules. Building has been treated as an isolated single zone. Hourly simulations have been conducted over one year period, for each of the 3 locations. This study includes five different types of windows (including low-e and solar control), six different glazed areas ranging from $20 \%$ to $90 \%$ (expressed as percentage of wall area). Table 1 describes the important properties of these five different glazings. Energy performance of each glazing 
has been analysed for four different orientations. Energy consumption of glass-curtain walls have been compared to an opaque wall with conventional glazed area $(20 \%$, double glazed clear glass window).

\section{Results and Discussion}

The analysis has been carried out for each of the five types of glazings, by taking the effect of glazed area, orientation, and climate on annual cooling and heating load.

4.1. Effect of Glazed Area. Effect of glazed area on building's cooling and heating load for all types of glazings and for all orientations is shown in Table 2(a) for Delhi, Table 2(b) for Jodhpur, and Table 2(c) for Chennai. These three tables are exhaustive in the sense that all the details are shown here. Results are shown in unit floor area.

4.2. Delhi. Table 2(a) shows that as glazed area increases, the energy consumption also increases, and this is already a wellknown fact. In what proportion the energy consumption increases with the glazed area depends upon building type, glazing type, glazing orientation, and climate type, and this is the subject matter of the present study. For this station and for south orientation, the results are shown in graphical form in Figure 3(a). This figure shows that energy consumption varies almost linearly with the glazed area (a straight line can be passed through tops of the bars for the same glazing). For $10 \%$ increment in glazed area, the corresponding increase in energy consumption is $15.3 \mathrm{kWh} / \mathrm{m}^{2} \mathrm{yr}$ for clear-clear glazing, $15.1 \mathrm{kWh} / \mathrm{m}^{2} \mathrm{yr}$ for low-e1-clear glazing, $10.9 \mathrm{kWh} / \mathrm{m}^{2} \mathrm{yr}$ for low-e2-clear glazing, $4.5 \mathrm{kWh} / \mathrm{m}^{2} \mathrm{yr}$ for solar control (absorptive), and $2.1 \mathrm{kWh} / \mathrm{m}^{2} \mathrm{yr}$ for solar control (reflective) glazing. The highest increment in energy consumption is for clear-clear glazing, and the lowest increment is for solar control (reflective) glazing.

4.3. Jodhpur. Results for this station are shown in Table 2(b) and Figure 3(b). Here, for $10 \%$ increase in glazed area, the corresponding increase in annual energy consumption is $18.3 \mathrm{kWh} / \mathrm{m}^{2} \mathrm{yr}$ for clear-clear glazing, $17.5 \mathrm{kWh} / \mathrm{m}^{2} \mathrm{yr}$ for low-e1-clear glazing, $12.8 \mathrm{kWh} / \mathrm{m}^{2} \mathrm{yr}$ for low-e2-clear glazing, $5.7 \mathrm{kWh} / \mathrm{m}^{2} \mathrm{yr}$ for solar control (absorptive) glazing, and $2.2 \mathrm{kWh} / \mathrm{m}^{2} \mathrm{yr}$ for solar control (reflective) glazing.

4.4. Chennai. Table 2(c) and Figure 3(c) show the effect of glazed area on annual energy consumption for this station. If the glazed area is increased by $10 \%$, the increase in annual energy consumption is $14.6 \mathrm{kWh} / \mathrm{m}^{2} \mathrm{yr}$ for clearclear glazing, $13.8 \mathrm{kWh} / \mathrm{m}^{2} \mathrm{yr}$ for low-e1-clear glazing, and $10.5 \mathrm{kWh} / \mathrm{m}^{2} \mathrm{yr}$ for low-e2-clear glazing, $5.4 \mathrm{kWh} / \mathrm{m}^{2} \mathrm{yr}$ for solar control (absorptive) glazing, and $2.4 \mathrm{kWh} / \mathrm{m}^{2} \mathrm{yr}$ for solar control (reflective) glazing.

4.5. Overheating in Winter. For Delhi station, when glazed area exceeds $20 \%$ value, building gets overheated even in winter and it requires cooling, subsequently. This holds true particularly for those glazings whose g-values are greater than 0.5 . Such glazings let in solar radiation excessively, and this results in overheating. For such curtain walls, on annual bases also, there is high requirement of heating/cooling energy. For Delhi station, the results are shown in Table 3, and here, the glass-curtain forms the south façade of the building. For the reference case, when the glazed area is $20 \%$ only (clear-clear glazing), during winter, there is no overheating, and, hence, cooling energy requirement is almost nil. A small amount of heating, $0.3 \mathrm{kWh} / \mathrm{m}^{2} \mathrm{yr}$, is required. For same case, during summer, the cooling energy requirement is $106.2 \mathrm{kWh} / \mathrm{m}^{2} \mathrm{yr}$. But if the glazed area becomes $90 \%$ and the type of glazing remains the same (clear-clear), there is overheating in winter (resulting in cooling load of $27.7 \mathrm{kWh} / \mathrm{m}^{2} \mathrm{yr}$ ). This also results in increased cooling load in summer $\left(191.2 \mathrm{kWh} / \mathrm{m}^{2} \mathrm{yr}\right)$. Overheating in winter occurs for both types of low-e windows. Only for both types of solar control glazings, overheating in winter is very low or negligible: being $2.5 \mathrm{kWh} / \mathrm{m}^{2} \mathrm{yr}$ for solar control (absorptive) glazing and $0.1 \mathrm{kWh} / \mathrm{m}^{2} \mathrm{yr}$ for reflective type solar control glazing. During summer, low-e glazings (both types) show low summer cooling load as compared to clear-clear glazing. The reduction in summer cooling load is very significant for both types of solar control glazings: being $122.3 \mathrm{kWh} / \mathrm{m}^{2} \mathrm{yr}$ for absorptive and $97.9 \mathrm{kWh} / \mathrm{m}^{2} \mathrm{yr}$ for reflective, respectively.

4.6. Effect of Orientation. Effect of orientation of glasscurtain wall on annual energy consumption is shown in Table 4. It is seen that south orientation corresponds to maximum annual heating/cooling load and it is minimum for north orientation. This fact holds good for all the stations. Building load for east and west orientation are almost equal (within 2\% variation) for all types of glazings and for all climates. Also energy requirement in east and west direction is slightly more (about 1-2\%) than north orientation. The reason is that: the beam radiation on east or west glazing is significant and has almost equal value, while it is almost nil on north glazing. Figure 4 shows the results for Delhi station. Here, annual building load for $20 \%$ glazed area (reference case, clear-clear) is normalized, so that the comparison of other glazing types with the reference case becomes simple. In south orientation and with respect to reference case, a clear-clear glass-curtain wall results in 106\% more energy requirement. Increased energy requirement for other glasscurtain walls are $104 \%$ for low-e1, $69 \%$ for low-e2, $18 \%$ for solar control (absorptive), and $-6 \%$ for solar control (reflective). The same trend is noticed for the other two stations also, Jodhpur and Chennai.

4.7. Effect of Climate. Effect of climate on comparison of glasscurtain wall with the reference case is shown in Figure 5. For each climate (or station), the annual energy consumption in the reference case is normalized to $100 \mathrm{kWh} / \mathrm{m}^{2} \mathrm{yr}$ in order to make the comparison simple. For composite climate of Delhi and with respect to reference case, a glass-curtain wall, made of clear-clear glazing, low-e1 glazing, low-e2 glazing, and solar control (absorptive) glazing shows 106\%, 104\%, 69\%, and $18 \%$ more energy consumption respectively, while glasscurtain wall made of solar control (reflective) glazing shows $6 \%$ less energy consumption. For dessert climate of Jodhpur, the corresponding values (in the same sequence) are 104\%, 


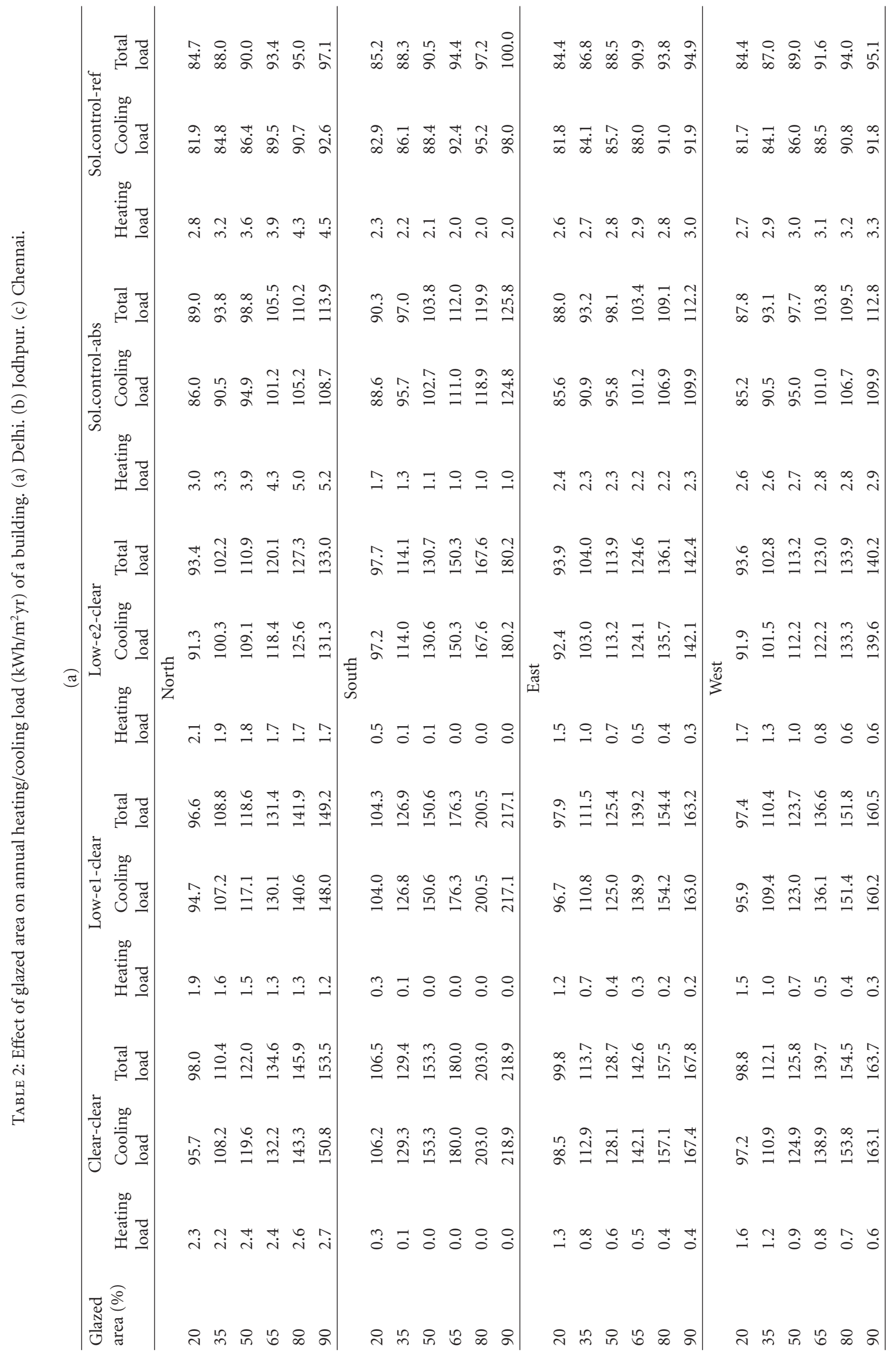




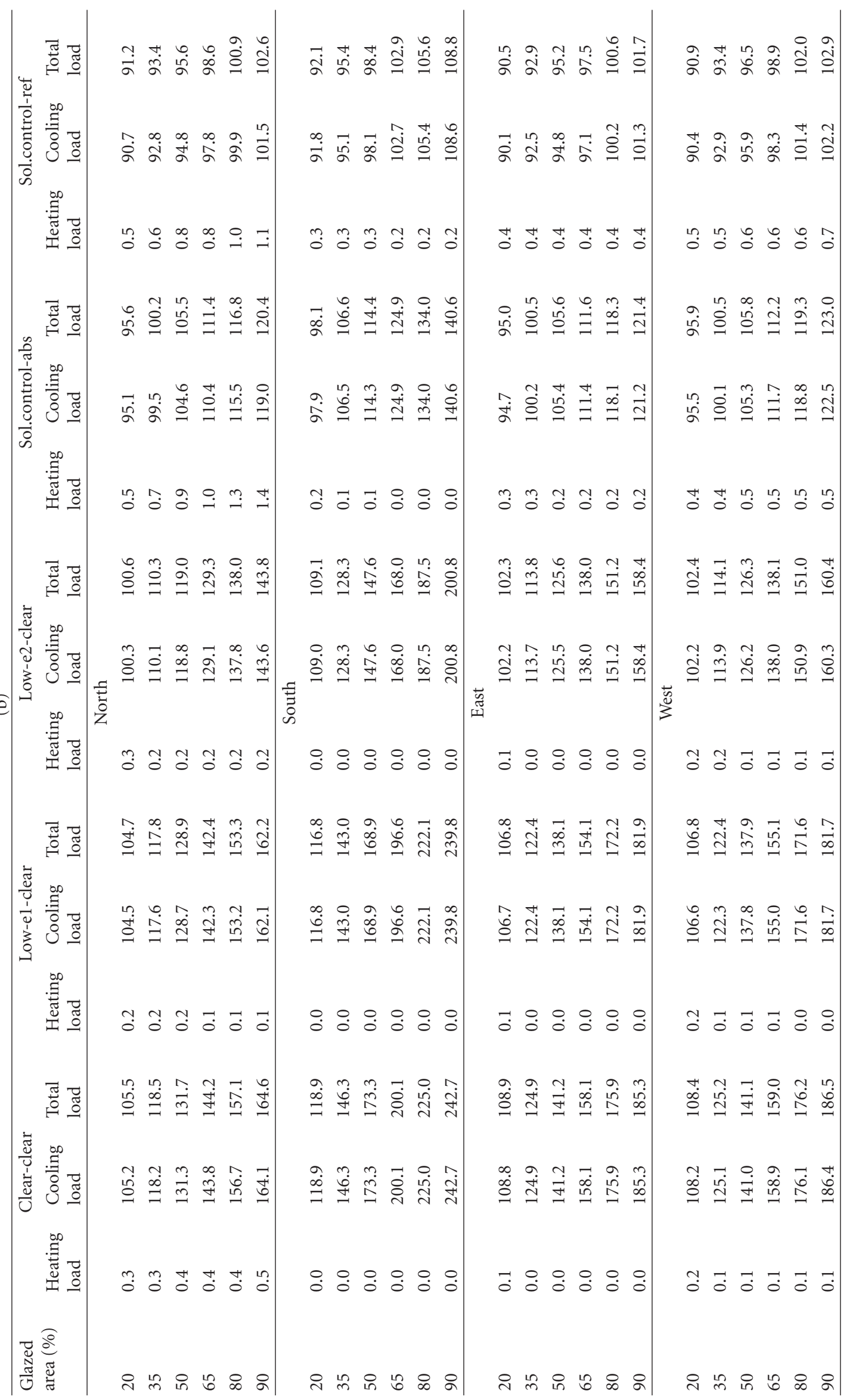




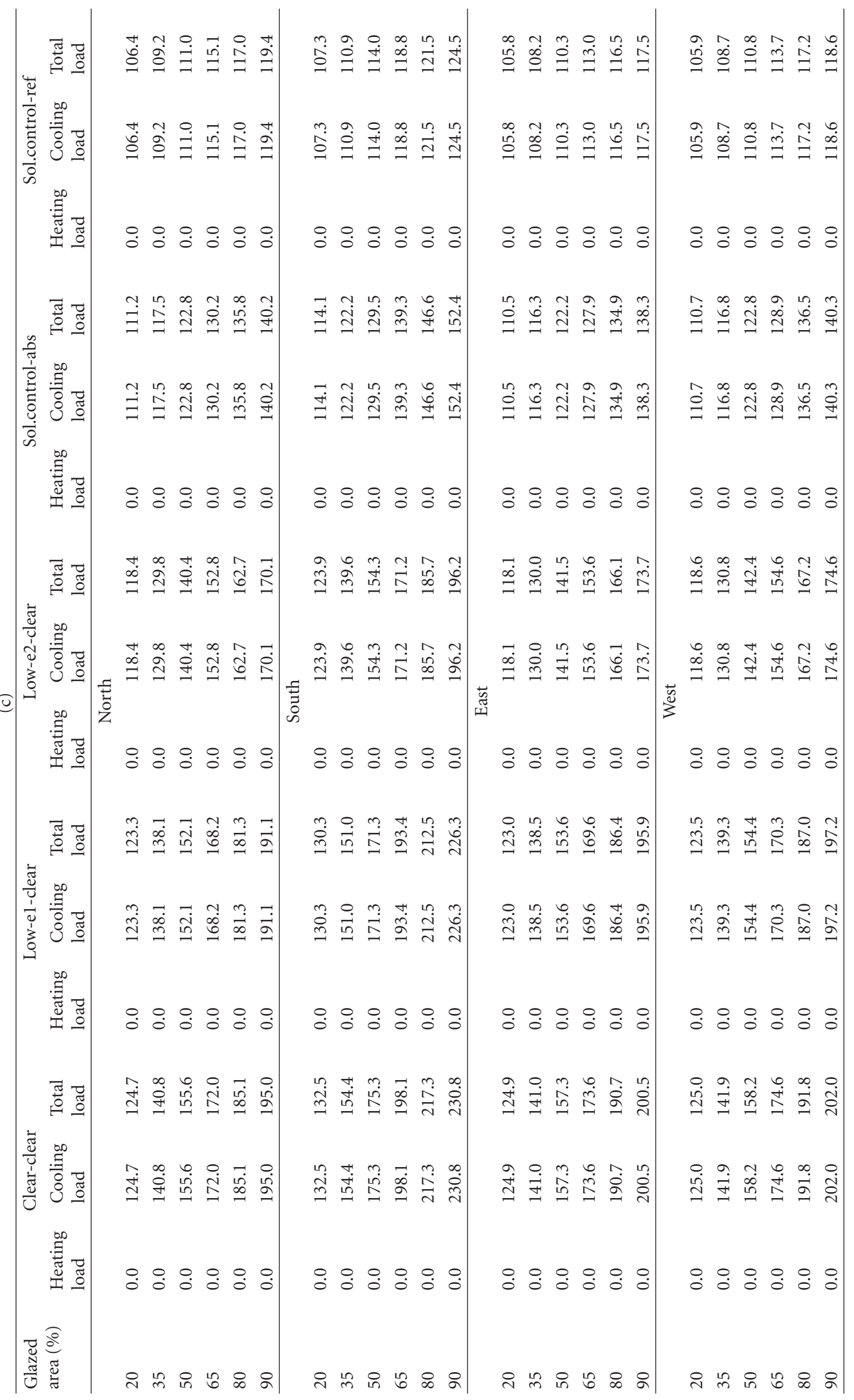




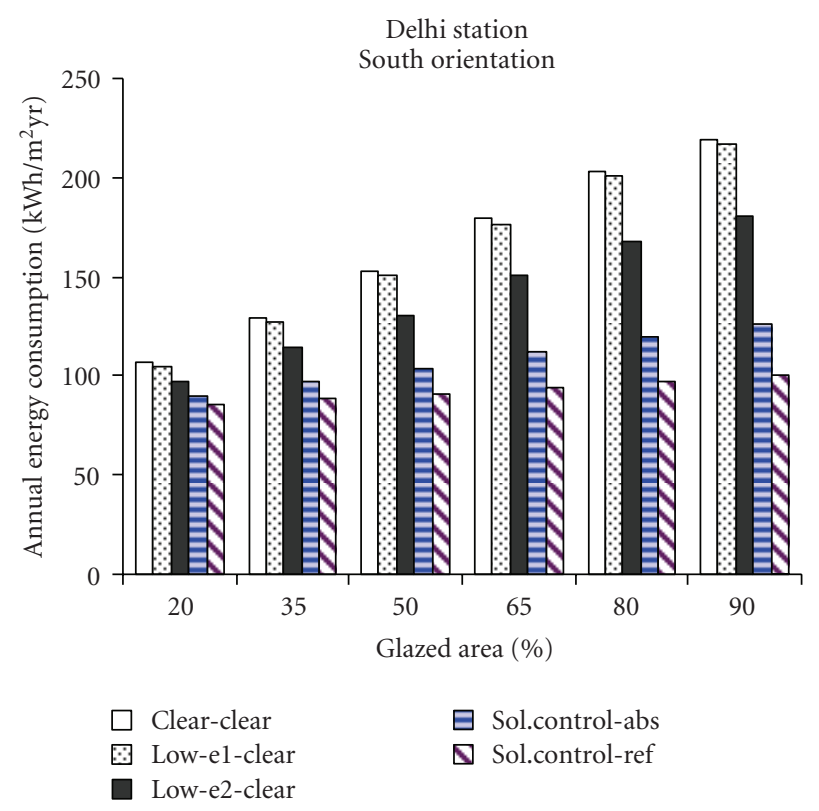

(a)

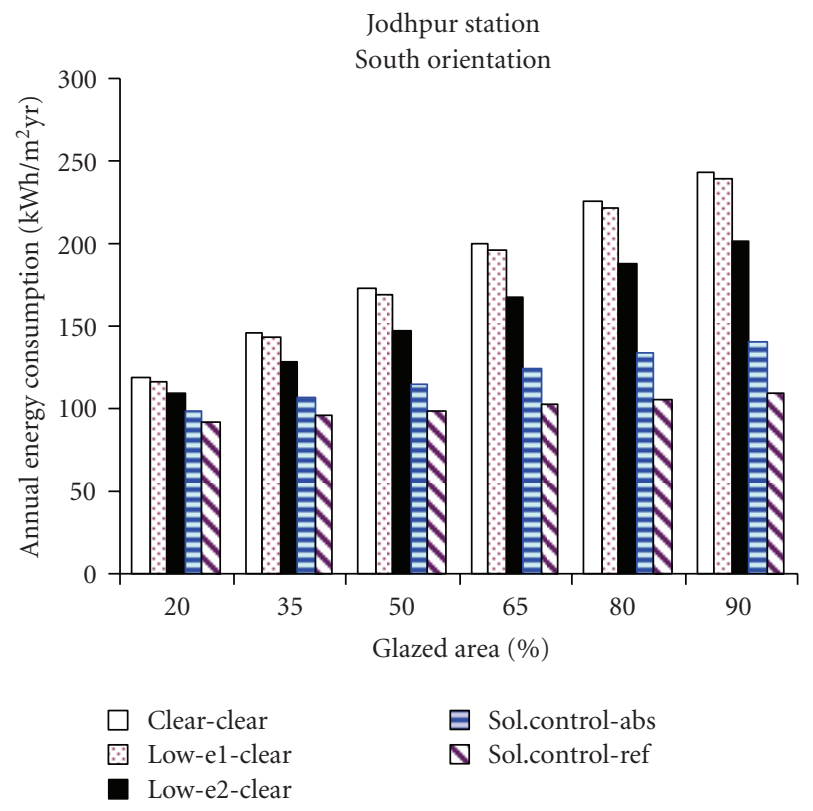

(b)

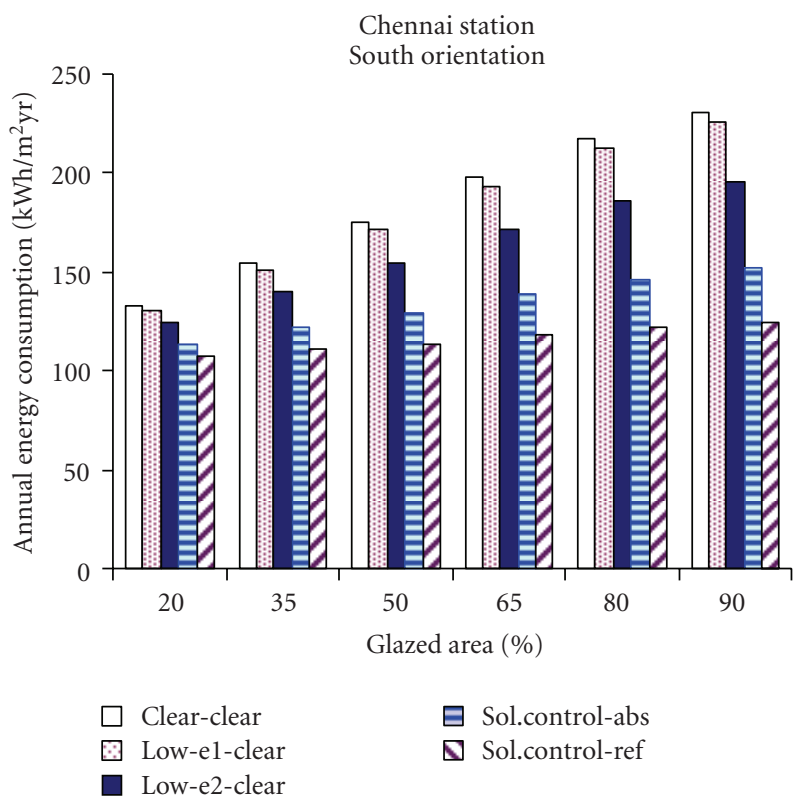

(c)

FIGURE 3: Effect of glazed area on annual energy consumption. Five types of glazings are considered.

TABLE 3: Some glass-curtain walls results in overheating in winter. Delhi station, south orientation.

\begin{tabular}{|c|c|c|c|c|c|}
\hline \multirow{3}{*}{ Glazing type } & \multirow{3}{*}{ Glazed area (\%) } & \multicolumn{4}{|c|}{ Annual energy consumption $\left(\mathrm{kWh} / \mathrm{m}^{2} \mathrm{yr}\right)$} \\
\hline & & \multirow{2}{*}{$\begin{array}{l}\text { Summer } \\
\text { Cooling }\end{array}$} & \multicolumn{2}{|c|}{ Winter } & \multirow[t]{2}{*}{ Annual } \\
\hline & & & Heating & Cooling & \\
\hline Clear-clear ( reference) & 20 & 106.2 & 0.3 & 0.0 & 106.5 \\
\hline Clear-clear & 90 & 191.2 & 0.0 & 27.7 & 218.9 \\
\hline Low-e1-clear & 90 & 187.6 & 0.0 & 29.5 & 217.1 \\
\hline Low-e2-clear & 90 & 161.4 & 0.0 & 18.8 & 180.2 \\
\hline Solar control-abs & 90 & 122.3 & 1.0 & 2.5 & 125.8 \\
\hline Solar control-ref & 90 & 97.9 & 2.0 & 0.1 & 100.0 \\
\hline
\end{tabular}




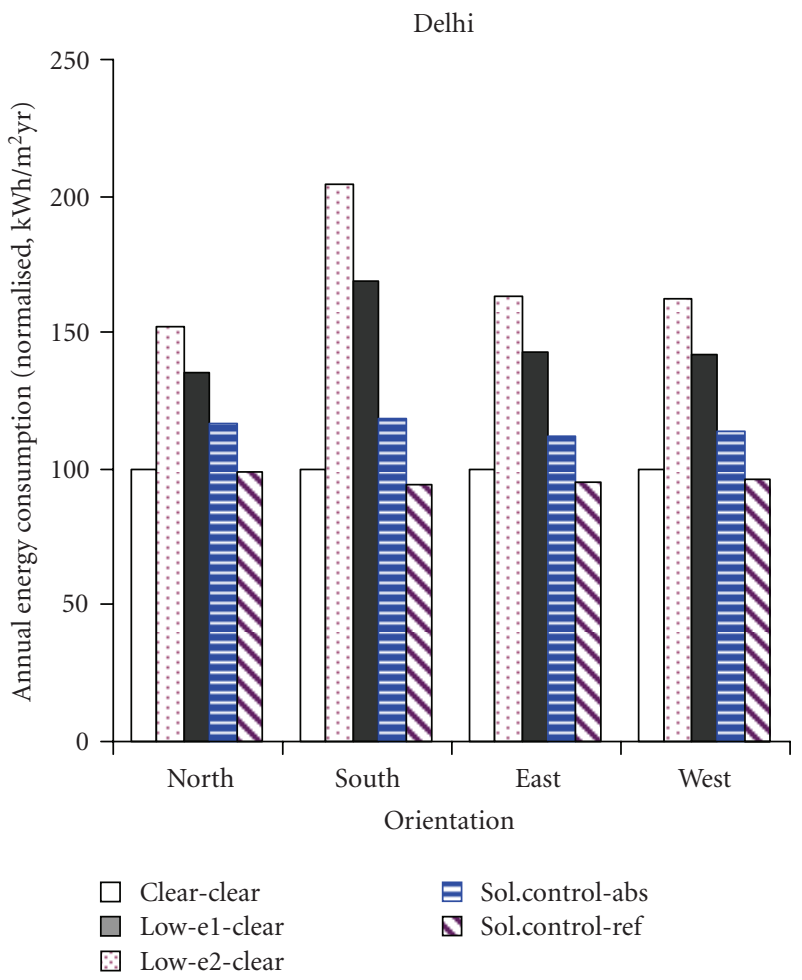

Figure 4: Effect of orientation on annual energy consumption. Four types of glass-curtain walls (90\% glazed area) are compared with reference case (20\% glazed area, clear-clear).

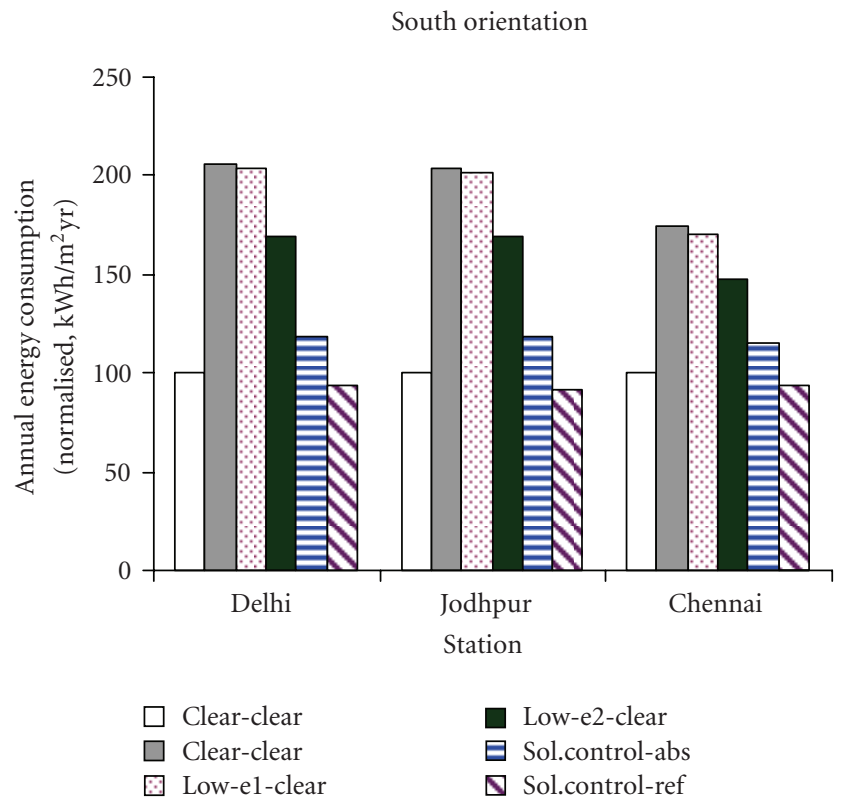

FIGURE 5: Effect of climate on comparison of glass-curtain walls with reference case.

$102 \%, 69 \%, 18 \%$, and $-8 \%$, respectively. For coastal climate of Chennai, the corresponding values are $74 \%, 71 \%, 48 \%$, $15 \%$, and $-6 \%$, respectively. This shows that for composite climate, low-e1 glass-curtain wall consumes 104\% more energy, while the same curtain wall, for coastal climate, consumes only $71 \%$ more energy. So climate has significant effect on this comparison. It is also evident that, for all three climates, curtain wall made of solar control glazing (reflective) consumes $6 \%-8 \%$ less energy than the reference case.

\section{Conclusions}

As the glazed area increases, the annual energy consumption increases. It is seen that this energy consumption increases 
TABLE 4: Effect of orientation of glass-curtain walls on building energy consumption.

\begin{tabular}{|c|c|c|c|c|c|c|}
\hline \multirow{2}{*}{ Station } & \multicolumn{6}{|c|}{ Annual energy consumption $\left(\mathrm{kWh} / \mathrm{m}^{2} \mathrm{yr}\right)$} \\
\hline & Glazing type & Glazed area $(\%)$ & North & South & East & West \\
\hline \multirow{6}{*}{ Delhi } & Clear-clear (reference) & 20 & 98.0 & 106.5 & 99.8 & 98.8 \\
\hline & Clear-clear & 90 & 153.5 & 218.9 & 167.8 & 163.7 \\
\hline & Low-e1-clear & 90 & 149.2 & 217.1 & 163.2 & 160.5 \\
\hline & Low-e2-clear & 90 & 133.0 & 180.2 & 142.4 & 140.2 \\
\hline & Sol.control-abs & 90 & 113.9 & 125.8 & 112.2 & 112.8 \\
\hline & Sol.control-ref & 90 & 97.1 & 100.0 & 94.9 & 95.1 \\
\hline \multirow{6}{*}{ Jodhpur } & Clear-clear (reference) & 20 & 105.5 & 118.9 & 108.9 & 108.4 \\
\hline & Clear-clear & 90 & 164.6 & 242.7 & 185.3 & 186.5 \\
\hline & Low-e1-clear & 90 & 162.2 & 239.8 & 181.9 & 181.7 \\
\hline & Low-e2-clear & 90 & 143.8 & 200.8 & 158.4 & 160.4 \\
\hline & Sol.control-abs & 90 & 120.4 & 140.6 & 121.4 & 123.0 \\
\hline & Sol.control-ref & 90 & 102.6 & 108.8 & 101.7 & 102.9 \\
\hline \multirow{6}{*}{ Chennai } & Clear-clear (reference) & 20 & 124.7 & 132.5 & 124.9 & 125.0 \\
\hline & Clear-clear & 90 & 195.0 & 230.8 & 200.5 & 202.0 \\
\hline & Low-e1-clear & 90 & 191.1 & 226.3 & 195.9 & 197.2 \\
\hline & Low-e2-clear & 90 & 170.1 & 196.2 & 173.7 & 174.6 \\
\hline & Sol.contro-abs & 90 & 140.2 & 152.4 & 138.3 & 140.3 \\
\hline & Sol.contro-ref & 90 & 119.4 & 124.5 & 117.5 & 118.6 \\
\hline
\end{tabular}

almost linearly with glazed area, for all types of glazings, for all climates, and for all orientations. For Delhi station with south orientation, $10 \%$ increment in glazed area leads to more energy consumption of $15.3 \mathrm{kWh} / \mathrm{m}^{2} \mathrm{yr}$ for clearclear glazing (highest increase) and $2.1 \mathrm{kWh} / \mathrm{m}^{2} \mathrm{yr}$ for solar control (reflective) glazing (lowest increase).

Glass-curtail wall, with south orientation, results in maximum heating/cooling load of a building, irrespective of the types of the glazings and the climates. Minimum energy consumption is for north oriented glass-curtain wall. For Jodhpur and for double glazed low-el glass-curtain wall, it is $239.8 \mathrm{kWh} / \mathrm{m}^{2} \mathrm{yr}$ for south orientation and $162.2 \mathrm{kWh} / \mathrm{m}^{2} \mathrm{yr}$ for north orientation.

Climate has significant effect on comparison of glasscurtain wall with the reference case (south orientation). A glass-curtain wall made of low-el glazing, with respect to to the reference case, consumes $103.9 \%$ more energy for the composite climate of Delhi and 71\% more energy for coastal climate of Chennai.

Out of five glazings analysed, a glass-curtain wall made of solar control glazing (reflective) results in almost equal annual heating/cooling load of the building as the reference case (clear-clear, 20\% glazed area). It holds true for all orientations and for all climatic conditions analysed. For south orientation and for 3 climates analysed, the glass- curtain wall consumes $6 \%-8 \%$ less energy than the reference case.

\section{Acknowledgment}

The first author is grateful to the Council for Scientific and Industrial Research (CSIR), New Delhi, for financial assistance.

\section{References}

[1] C. Bouden, "Influence of glass curtain walls on the building thermal energy consumption under Tunisian climatic conditions: the case of administrative buildings," Renewable Energy, vol. 32, no. 1, pp. 141-156, 2007.

[2] N. K. Bansal, S. N. Garg, N. Lugani, and M. S. Bhandari, "Determination of glazing area in direct gain systems for three different climatic zones," Solar Energy, vol. 53, no. 1, pp. 8190, 1994.

[3] N. I. Al-Hamdani and A. I. Ahmad, "Effect of window parameters on indoor thermal environment of buildings," Solar and Wind Technology, vol. 4, no. 1, pp. 71-75, 1987.

[4] S. Saridar and H. Elkadi, "The impact of applying recent façade technology on daylighting performance in buildings in eastern Mediterranean," Building and Environment, vol. 37, no. 11, pp. 1205-1212, 2002. 
[5] Y. V. Perez and I. G. Capeluto, "Climatic considerations in school building design in the hot-humid climate for reducing energy consumption," Applied Energy, vol. 86, no. 3, pp. 340348, 2009.

[6] R. Johnson, S. Selkowitz, F. Winkelmann, and M. Zentner, "Glazing optimization study for energy efficiency in commercial office buildings," Tech. Rep. LBL-12764, pp. 1-10, Lawrence Berkeley National Laboratory, 1981.

[7] R. Johnson, S. Selkowitz, and R. Sullivan, "How fenestration can significantly affect energy use in commercial buildings," Tech. Rep. LBL-17330, pp. 1-14, Lawrence Berkeley National Laboratory, 1984.

[8] H. Bulow-Hube, "The effect of glazing type and size on annual heating and cooling demand for Swedish offices," in Proceedings of the Renewable Energy Technologies in Cold Climates, pp. 188-193, Montreal, Canada, 1998, Conference46.

[9] M. L. Persson, A. Roos, and M. Wall, "Influence of window size on the energy balance of low energy houses," Energy and Buildings, vol. 38, no. 3, pp. 181-188, 2006.

[10] M. Bojić and F. Yik, "Application of advanced glazing to high-rise residential buildings in Hong Kong," Building and Environment, vol. 42, no. 2, pp. 820-828, 2007.

[11] M. M. Aboulnaga, "Towards green buildings: glass as a building element-the use and misuse in the gulf region," Renewable Energy, vol. 31, no. 5, pp. 631-653, 2006.

[12] M. C. Singh, S. N. Garg, and R. Jha, "Different glazing systems and their impact on human thermal comfort-Indian scenario," Building and Environment, vol. 43, no. 10, pp. 1596-1602, 2008.

[13] T. Frank, "Climate change impacts on building heating and cooling energy demand in Switzerland," Energy and Buildings, vol. 37, no. 11, pp. 1175-1185, 2005.

[14] I. Singh, Heat transfer in fenestration systems and energy savings: buildings in India, Ph.D. thesis, Centre for Energy Studies, Indian Institute of Technology, New Delhi, India, 2002.

[15] Energy Conservation Building Code in India, Bureau of Energy Efficiency, New Delhi, India, 2006.

[16] SP: 41 (S\&T), Hand Book of Functional Requirements of Buildings, Bureau of Indian Standards (BIS), New Delhi, India, 1987.

[17] TRNSYS, “A transient system simulation program,” Tech. Rep. W E-53706, pp. 1-82, Solar Energy laboratory, University of Wisconsin, Madison, Wis, USA, 2004. 

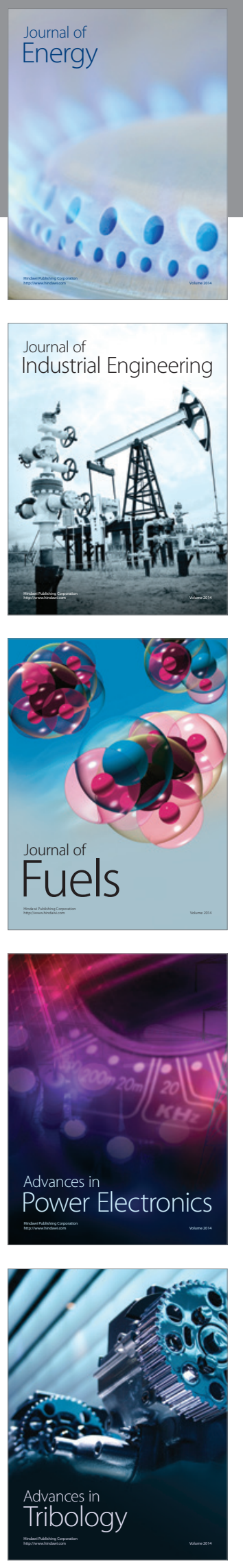
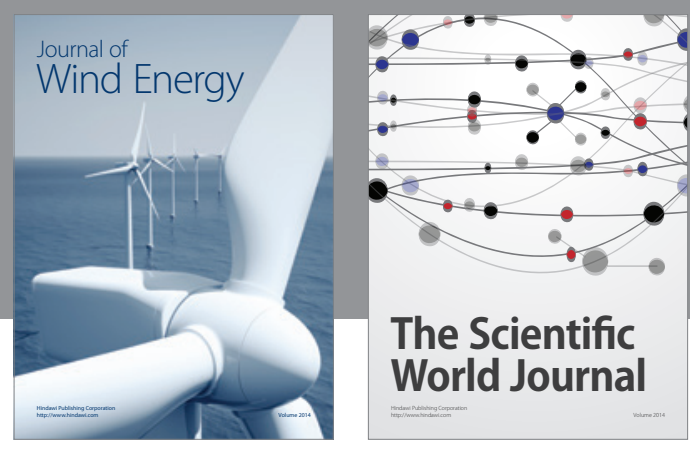

The Scientific World Journal

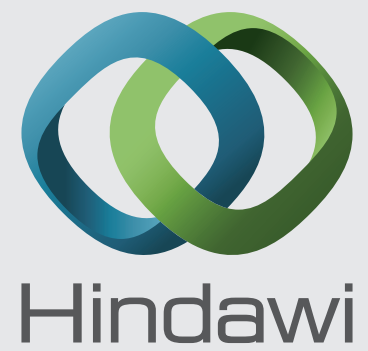

Submit your manuscripts at http://www.hindawi.com
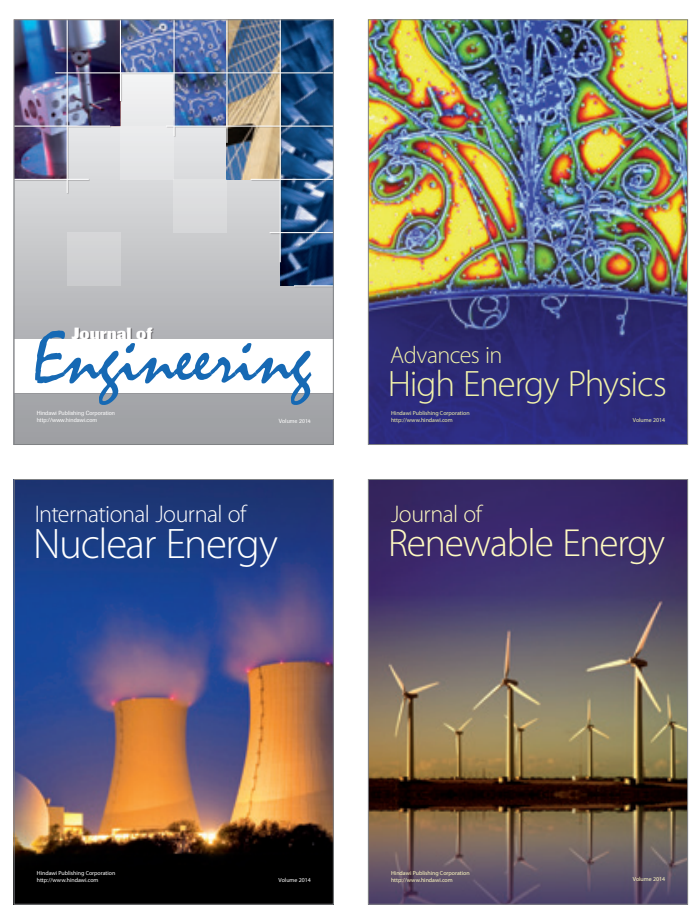

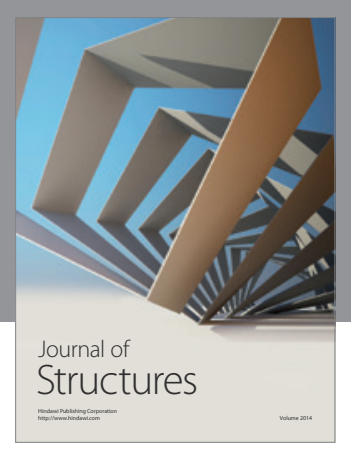

Rotating
Mechinery
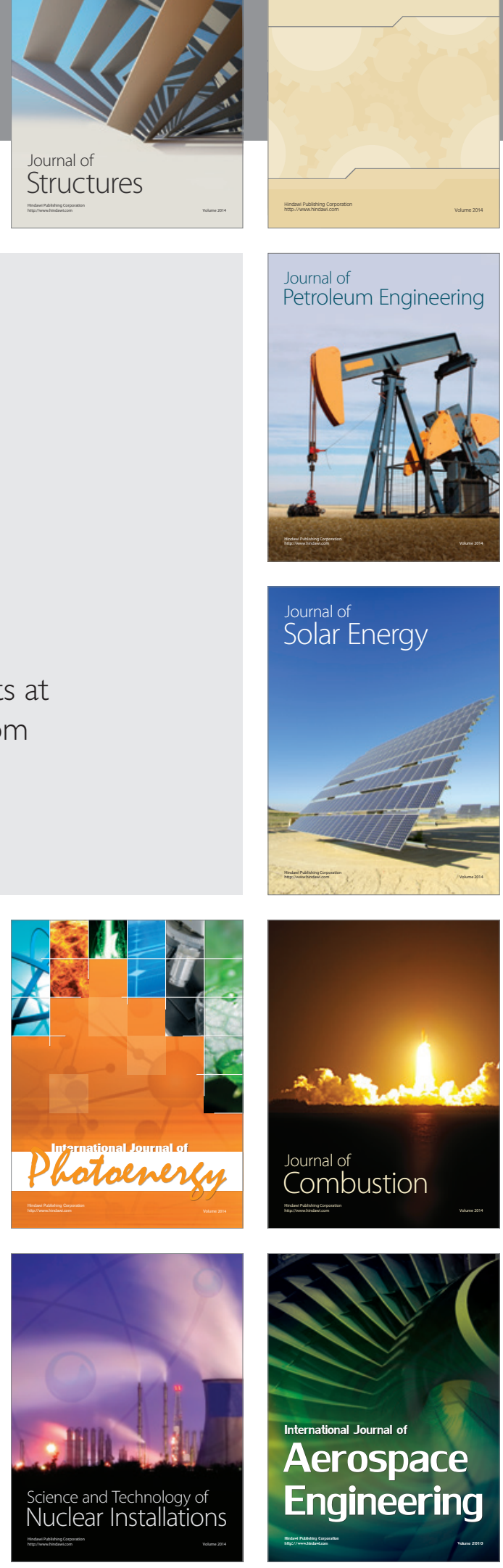